\title{
Anti-Vibrio Response of CarcininPm 1 from Penaeus monodon and Its Heterologous Expression
}

\author{
Liang Zhou ${ }^{1}$, Guoqiang $\mathrm{Li}^{1}$, Anguo Li ${ }^{1}$, Yang Jiao ${ }^{1}$,Jianhua Huang ${ }^{2}$, and Chaogang Wang ${ }^{{ }^{*}}$ \\ ${ }^{1}$ Guangdong Technology Research Center for Marine Algal Bioengineering, College of Life Sciences and Oceanography, Shenzhen \\ University, Shenzhen 518060, PR China \\ ${ }^{2}$ South China Sea Fisheries Research Institute, Chinese Academy of Fishery Sciences, Guangzhou, 518121, PR China
}

\begin{abstract}
Crustins are crucial antimicrobial peptides in shrimp and play very important roles in innate immunity. In this research, a Type I crustin from Penaeus monodon (CarcininPm1) contained 108 residues was studied. The first 16 residues are signal peptide. It contained ten cysteines but did not form an intact whey acidic protein (WAP) domain. Carcinin $P m 1$ was observed to widely distribute in all tissues, while highly expressed in intestine. The expression level of Carcinin $P m 1$ in hepatopancreas was up-regulated 1220 times during 4-12h post challenged by Vibrio parahaemolyticus. And the transcription in heart, stomach and gills was also significantly enhanced at $4 \mathrm{~h}$ post challenge. The mature peptide was expressed successfully in Eschericha coli by fusing to a SUMO protein, with protein production around $8 \mathrm{mg} / \mathrm{mL}$. After cleavage with SUMO protease, carcinin $P m 1$ was obtained indicating its potential applications.
\end{abstract}

\section{Introduction}

Antimicrobial peptides (AMPs) are small and active peptides widely distributed in various organisms, as an important part of innate immunity of organisms and exhibited broad-spectrum of antimicrobial activities against variety of bacteria, virus and cancer cells [1].

Penaeus monodon, also called black tiger shrimp, is the second most widely cultured shrimp species in the world. However, the outbreak of diseases seriously reduced the production and economic benefit, especially infections caused by Vibrios[2] or viruses [3]. As invertebrates do not have acquired immune system, they depend on innate immunity to defend invading microbes[4]. Innate immunity includes humoral and cellular immunity. Antimicrobial peptides (AMP) are important humoral immunity molecules, as they can kill invading microbes directly and/or regulate other immune response[5,6]. Several types of AMPs were identified in shrimps, including crustins, penaeidins, antilipopolysaccharide factors (ALFs), stylicins, haemocyanin-derived peptides, lysozymes and histones and derived fragments [6-8].

Crustin is one of the largest families of AMPs in invertebrate. There are in total four types of crustins in crustaceans [9]. Type I crustins are constituted by a signal peptide, a cysteine-rich domain with two disulfide bridges and a single WAP (whey acidic protein) domain at the $\mathrm{C}$-terminus. Compared to Type I crustins, the type II crustins contain a long glycine-rich region to the Nterminus of the cysteine-rich domain. Type III crustins, also called single WAP domain (SWD) containing proteins, only contain a short proline and arginine-rich region in front of the WAP domain [10,11]. The type IV crustins (DWD crustins) have two WAP domains [11].

So far, four types of crustins have been found in $P$. monodon. Only two Type I crustins have been mentioned, while at least ten kinds of Type II crustins were discovered [12]. CrustinPm1 and crustinPm5 exhibit antimicrobial activity only against Gram-positive bacteria, while crustinPm7 is active against both Grampositive and Gram-negative bacteria [13-15]. Type III crustin from $P$. monodon exhibits anti-Gram-positive, but not anti-Gram-negative bacteria activity and it is a competitive inhibitor of subtilisin A [16]. However, the DWD crustins do not show apparent activity [17].

Type I crustins are present mainly in crabs[18,19] but also found in crayfish[20-22] and shrimps [23-25]. Some shrimps contain more than one isoforms of Type I crustins. The first Type I crustin was isolated in 1999, from the granular haemocytes of the shore crab, Carcinus maenas and named carcinin $\mathrm{Cm} 1$. It was heat stable and active only against Gram-positive bacteria [26]. There are in total five type I crustins identified in Marsupenaeus japonicas [24-25].

The type I crustin CarcininPm1, was first reported by Suchao Donpudsa, et.al.[12]. However, it was not fully characterized. In this research, further studies were performed to reveal its sequence similarity with other type I crustin, the tissue distribution and expression trend during Vibrio infection. All the results suggest that it could play a very important role in the innate immunity system of P. monodon. 


\section{Materials and Methods}

\subsection{Bioinformatics analysis of CarcininPm1}

The nucleotide sequence of Carcinin $P m 1$ was obtained from transcriptome sequencing data of the hepatopancreas of Penaeus monodon. The Open Reading Frame and amino acid sequence of Carcinin $P m 1$ were deduced by ORF Finder (http://www.ncbi.nlm.nih.gov/ gorf/gorf.html).The signal peptide was predicted with signalP 4.0 server. DNAman version 6 was used for generating gene structure information. Homologous sequences of Carcinin Pm 1 were obtained by Basic Local Alignment Search Tool (BLASTP)and multisequences alignment was performed with clustalw (https://www.genome.jp/tools-bin/clustalw). The online software ESPript 3.0 was used to generate the alignment result [27]. The physicochemical properties were predicted with the online software Protparam (http://web.expasy.org/protparam/).

\subsection{Immune challenging of shrimps and tissues collection}

Individual shrimps (about $16 \mathrm{~cm}$ in length) were collected from a prawn breeding base (Dapeng, Shenzhen), and cultured in $50 \mathrm{~L}$ glass boxes, each containing $10 \mathrm{~L}$ of filtered seawater at $25 \pm 1^{\circ} \mathrm{C}$ for one day before experiments.

Vibrio parahaemolyticus (SIV) was cultured with Luria-Bertani broth containing $3 \% \mathrm{NaCl}$ shaken at $30^{\circ} \mathrm{C}$. The overnight cultured bacteria were inoculated to a fresh media and cultured until OD540 reached 0.3 (about $5 \times 10^{7} \mathrm{CFU} / \mathrm{ml}$ ). Cells were harvested, washed twice with sterilized PBS and then resuspended with PBS to a final concentration of $1 \times 10^{7} \mathrm{CFU} / \mathrm{ml}$.

The shrimps were divided into two groups, Group P and Group V. Each group contained at least 20 individuals. For shrimps in group $\mathrm{V}, 100 \mu \mathrm{l}$ suspended bacteria were injected into the ventral blood sinusand shrimps in group P were injected with $100 \mu \mathrm{l}$ PBS as a control.Hepatopancreas of Group $\mathrm{P}$ and Group V shrimps were collected at $0,2,4,8,12$ and $24 \mathrm{~h}$ post injection. Heart, gills, stomach, intestine and hemocytes were collected from unchallenged and $4 \mathrm{~h}$ postchallenged shrimps.

To collect hemocytes, at least $600 \mu$ hemolymph was drawn out from pericardial sinus of shrimps with a $1 \mathrm{ml}$ syringe preloaded $100 \mu \mathrm{l}$ anticoagulant $(0.1 \mathrm{M}$ Sodium Citrate, $0.25 \mathrm{M}$ sucrose, $0.01 \mathrm{M}$ Tris- $\mathrm{HCl}, \mathrm{pH} 7.6)$ and centrifuged at $830 \mathrm{~g}, 4^{\circ} \mathrm{C}$ for $10 \mathrm{~min}$. The collected cells were washed with $1 \mathrm{ml}$ anticoagulant and then suspended in $600 \mu \mathrm{l}$ lysis buffer to proceed with the subsequent total RNA extraction.

\subsection{Total RNAs extraction and cDNAs synthesis}

Total RNAs were extracted from all the tissues prepared above using RNeasy Mini Kit (Qiagen, USA), according to the manufacturer's instruction. cDNAs were synthesized with PrimeScript RT reagent Kit with gDNA Eraser (Takara, Japan).

\subsection{Confirmation of the Carcinin Pm1 gene}

Reverse-transcription PCR(RT-PCR) was performed with primers Carcinin $P m 1$ conF and Carcinin $P m 1$ conR (Table 1) to amplify the ORF of Carcinin Pm1. The PCR product was connected to a T-vector (pMD ${ }^{\mathrm{TM}} 18-\mathrm{T}$ Vector Cloning Kit, Takara) and sequenced.

Table 1.Primers used in the present study.

\begin{tabular}{|c|c|}
\hline Name & Primer sequence (5'-3') \\
\hline $\begin{array}{c}\text { Carcinin } P m 1 \\
\text { conF }\end{array}$ & AACGAGTTCATCGTCAAGCAAATT \\
\hline $\begin{array}{c}\text { Carcinin } P m 1 \\
\text { conR }\end{array}$ & GCGCATCCGATTCCAAGTTG \\
\hline $\begin{array}{c}\text { Carcinin } P m 1 \\
\mathrm{~F}\end{array}$ & GGTGCCGTCTTCTCCCAAAC \\
\hline $\begin{array}{c}\text { Carcinin } P m 1 \\
\mathrm{R}\end{array}$ & GGATGTCCAGCTCCCTCTGC \\
\hline $\begin{array}{c}\text { EF-1 } \alpha \mathrm{F} \\
\text { EF- } 1 \alpha \mathrm{R}\end{array}$ & TGACAGCACCGAGCCCAAG \\
\hline
\end{tabular}

\subsection{Tissue distribution of CarcininPm1}

Semi-quantitative real-time PCR was used to test the relative expression level of Carcinin $P m 1$ in different tissues of $P$. monodon. One pair of primers (Carcinin $P m 1 \mathrm{~F}$ and Carcinin $P m 1 \mathrm{R}$ ) was used and EFlawas used as a control. The cDNAs of six different tissues from unchallenged shrimps were used as templates. The PCR protocol is as follows: $94{ }^{\circ} \mathrm{C}$ for 3 min; 30 cycles of $94{ }^{\circ} \mathrm{C}$ for $30 \mathrm{~s}, 55^{\circ} \mathrm{C}$ for $30 \mathrm{~s}, 72{ }^{\circ} \mathrm{C}$ for $15 \mathrm{~s}$, and $72{ }^{\circ} \mathrm{C}$ for $10 \mathrm{~min}$. The PCR product was checked by electrophoresis on a $2 \%$ agarose gel.

\subsection{Response of CarcininPm1 to SIV challenge}

Quantitative real-time PCR was performed to check the expression trend of CarcininPm1 in hepatopancreas and other tissues after Vibrio challenge. The qRT-PCR was performed on ViiA7 Real-time PCR system (ABI), with SYBR Premix Ex Taq II (TaKaRa, Japan).The same primers and control gene as in 2.4 were used. The cDNAs from PBS or $V$. parahaemolyticus challenged shrimps were used as templates. The qRT-PCR was performed with $95{ }^{\circ} \mathrm{C}, 30 \mathrm{~s} ; 40$ cycles of $95{ }^{\circ} \mathrm{C}, 5 \mathrm{~s}$ and $60{ }^{\circ} \mathrm{C}, 34 \mathrm{~s}$; and a melt from $60^{\circ} \mathrm{C}$ to $95{ }^{\circ} \mathrm{C}$. The experiment was repeated three times with individual templates. $2^{-\triangle \triangle \mathrm{CT}}$ method was used for expression profile analysis.

\subsection{Gene synthesis and vector construction}

The mature peptide of CarcininPm1 was fused to the Cterminus of a SUMO protein with His-tag and 
overexpressed in Escherichia coliBL21 (DE3). The nucleotide sequence of His-SUMO-Carcinin Pm 1 with NdeI and SacI cut sites in both ends was codon optimized for E. coli and chemically synthesized (General Biosystems, Inc., Hefei, China). The synthesized DNA was then linked to pColdIV vector by NdeI and SacI cut sites. The reconstituted plasmid was transformed to E. coli BL21 Rosetta (DE3), named BL21-carpm1.

\subsection{Protein expression and purification}

Adding $20 \mathrm{~mL}$ of overnight cultivated BL21-carpm1 intothe fresh $2 \mathrm{~L} \mathrm{LB}$ broth medium containing ampicillin $(50 \mu \mathrm{g} / \mathrm{mL})$ and then cultivating them at $37{ }^{\circ} \mathrm{C}$ with shaking at $200 \mathrm{rpm}$ until the absorbance reached 0.5 at $600 \mathrm{~nm}$. IPTG was added to the culture at a final concentration of $1 \mathrm{mM}$. The induction was performed at $16^{\circ} \mathrm{C}$ for 12 hours. Cells were harvested by centrifugation and the cell pelletswere washed and resuspended in PBS. The bacterial suspensions were then disrupted by ultrasonication. The supernatant (soluble fraction) was collected and analyzed by SDS-PAGE.

The fusion protein was purified by Ni-NTA Sepharose Fast Flow (Ruidahenghui, Beijing, China), and the his-tagged protein was eluted with buffer contained $50 \mathrm{mM}$ PBS, $300 \mathrm{mM} \mathrm{NaCl}$ and $200 \mathrm{mM}$ imidazole. Elutes were further analyzed by SDS-PAGE.

The eluted protein was further dialyzed against $50 \mathrm{mM}$ Tris- $\mathrm{HCl}, 200 \mathrm{mM} \mathrm{NaCl}$ to remove the imidazole and then quantified by Bradford reagent (Sangon, China). $100 \mu \mathrm{g}$ protein was mixed with $1 \mathrm{U}$ SUMO protease (General Biosystems, Inc., Hefei, China), and incubated at $4^{\circ} \mathrm{C}$ overnight to remove the SUMO tag.

\section{Results}

\subsection{Sequence information of Carcinin Pm1}

The nucleotide sequence of Carcinin $P m 1$ in this research was obtained from transcriptome data of hepatopancreas of $P$. monodonand was confirmed by RT-PCR. The deduced amino acid sequence is the same as the Carcinin $P m 1$ identified from EST database of $P$. monodonby Suchao Donpudsa, et.al., and it was classified as Type I crustin [12].The carcininPm1 gene is $327 \mathrm{bp}$ in length, encoding a 108-residues peptide and the first 16 residues constituted a signal peptide. The 92 residues mature peptide contained 10 cysteines in total (Figure 1). The first four cysteines were in the cysteine rich region and the rest six cysteines constituted an incomplete WAP domain. The molecular weight is $10.6 \mathrm{kDa}$ and the theoretical $\mathrm{p} I$ is 5.47 .

\subsection{Alignment of CarcininPm1 with other Type I crustins}

Carcinin $P m 1$ showed $70 \%$ identity with crustinI-5 from Penaeus japonicas (ANA91277.1), and 33\%-40\% sequence alignment indicated that the ten cysteines and their flanking residues are conserved. Notably, dentity with the other four crustins in Figure 2. The CarcininPm 1 and CrustinI-5 contained less cysteine residues in the mature peptide region compared to the other four crustins.

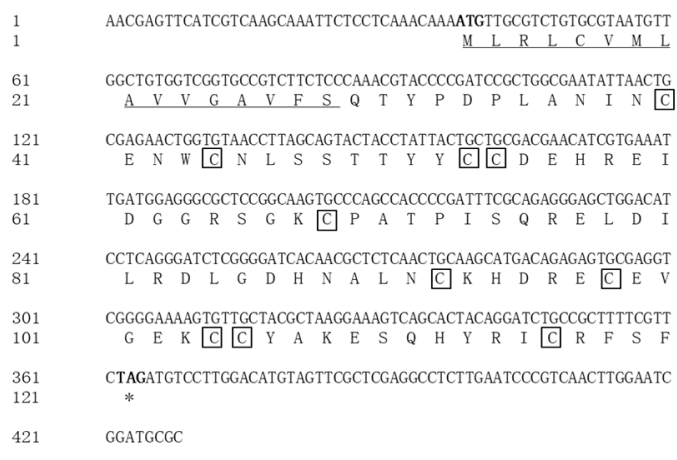

Fig. 1.Nucleotide and amino acid sequence of Carcinin $P m 1$. The initiation and termination codons were bolded; the signal peptide was underlined; the cysteines were in boxes.

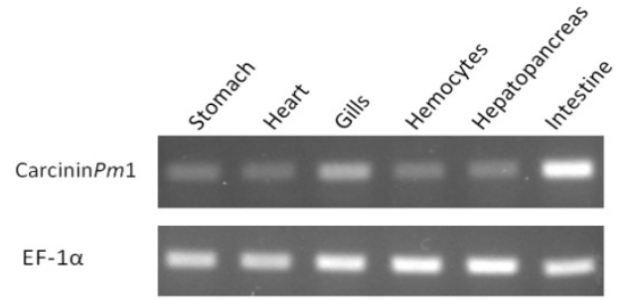

Fig. 3.Tissue distribution of Carcinin $P m 1$ in $P$. monodon tested by semi-quantified RT-PCR. EF-1 $\alpha$ was used as a control.

\subsection{Tissue distribution of CarcininPm1 in $P$. monodon}

The tissue distribution results (Figure 3) showed that Carcinin $P m 1$ could be detected in all tissues of $P$. monodon tested. It was highly expressed in intestine and the expression level in gills was relatively higher compared to that in the other four tissues.

\subsection{Response of CarcininPm1 to Vibrio challenge}

The expression of CarcininPm1 in hepatopancreas of P.monodon was up-regulated significantly when the shrimp was challenged by SIV(Figure 4A). About 12-20 times upregulation was detected at 4 and $12 \mathrm{~h}$ post challenge. And then the expression returned to the normal level post 24 hours. This is in accordance with the transcriptome sequencing result, which showed that the expression level of Carcinin $P m 1$ increased 16 times at $3 \mathrm{~h}$ post challenge. The expression level of Carcinin $P m 1$ in other tissues also increased significantly at $4 \mathrm{~h}$ post infection (Figure 4B). The most significant upregulation was in heart, stomach and gills (12-15 fold). The transcription was up-regulated about 8 times in hemocytes and about 3 times in intestine. 


\subsection{Vector construction, recombination expression of CarcininPm1}

pCold IV vector. The molecular weight of CarcininPm 1 was $10.64 \mathrm{kDa}$ as shown on SDS-PAGE (Figure 6C).

The mature peptide of Carcinin Pm 1 contained 92 residues was linked with SUMO protein with His- tag (Figure 5). The His-SUMO-Carcinin $P m 1$ was linked to

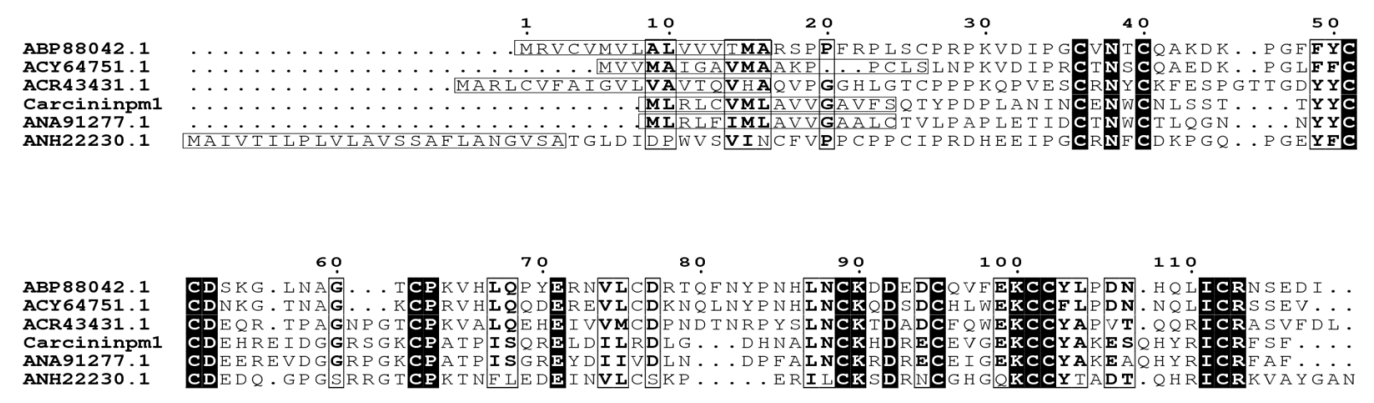

Fig. 2.Alignment of Carcinin $P m 1$ with other crustins. Identical residues were indicated with reverse color; similar residues were in bold and boxed. The signal peptides were in boxes. The GenBank accession number: ANA91277.1, crustinI-5 (Penaeus japonicas); ACR43431.1, crustin type I (Macrobrachium rosenbergii); ANH22230.1, crustin (Macrobrachium rosenbergii); ABP88042.1, P1crustin 1 (Pacifastacus leniusculus); ACY64751.1, crustin 1 (Procambarus clarkia)

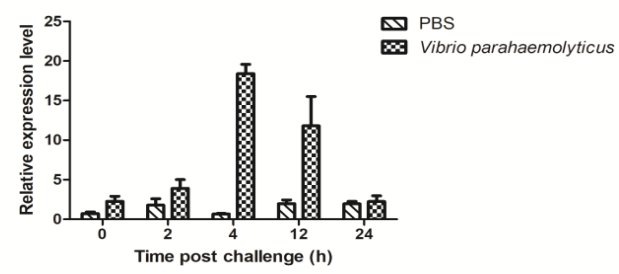

B

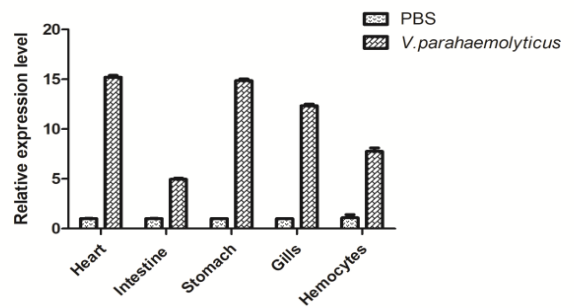

Fig. 4.Expression patterns ofCarcinin $P m 1$ in P.monodonpost $V$. parahaemolyticus challenge. A,Relative expression levelofCarcinin $P m 1$ in hepatopancreas at different time point post challenge. B. Relative expression level of Carcinin $P m 1$ in different tissues at $4 \mathrm{~h}$ post infection. Shrimps were injected with $V$. parahaemolyticus or PBS as control. qPCR was used to test the relative expression level.

\subsection{Purification of CarcininPm1}

The His-SUMO-CarcininPm 1 fusion protein was highly expressed in E.coli induced with IPTG at low temperature and half protein was in the supernatant (Figure 6A). The fusion protein was purified with a NiNTA column and eluted by $500 \mathrm{mM}$ imidozol as a pure

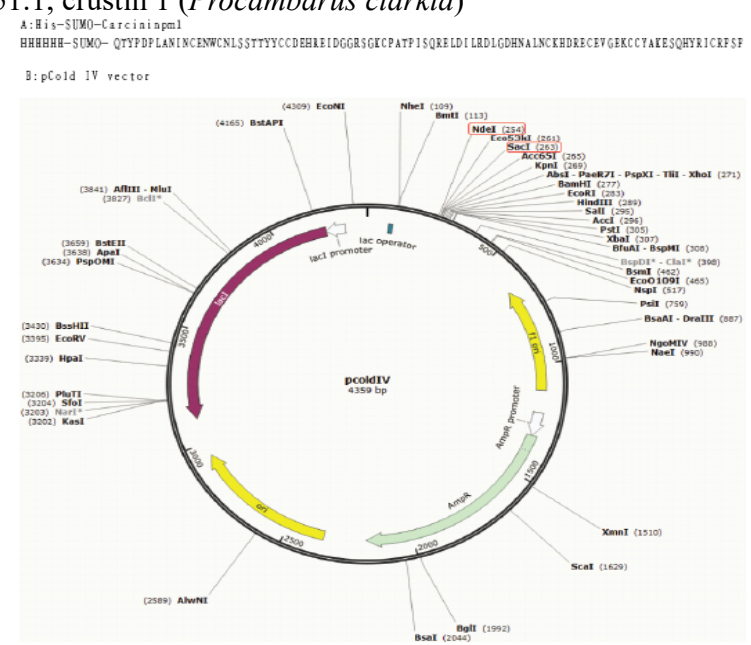

Fig.5. Construction of recombination plasmid. A, Amino acid sequence of His-SUMO-Carcinin Pm 1 . $\mathrm{B}$, Schematic representation of pCold IV vector.

protein (Figure 6B). The yield of purified SUMOCarcinin $P m 1$ was around $8 \mathrm{mg} / \mathrm{mL}$, measured by bradford reagent.And then the SUMO tag was successfully removed by cutting with a SUMO protease, shown that a $\sim 10.64 \mathrm{kDa}$ band was detected on SDSPAGE (Figure 6C). 


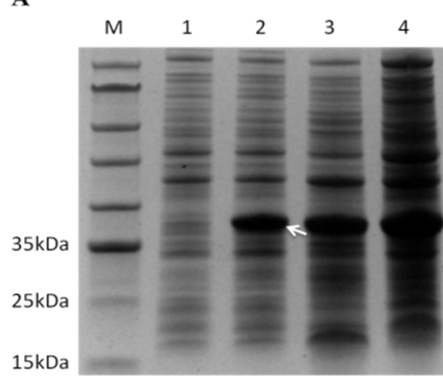

B

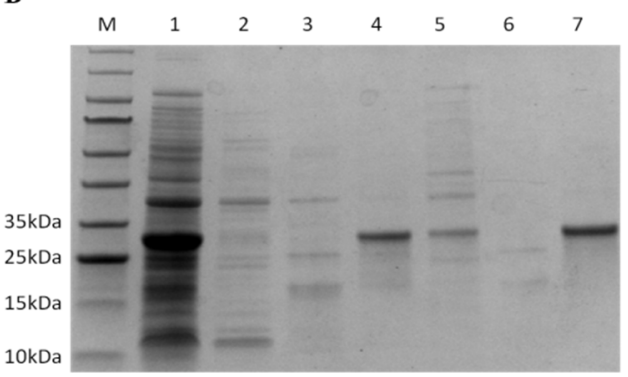

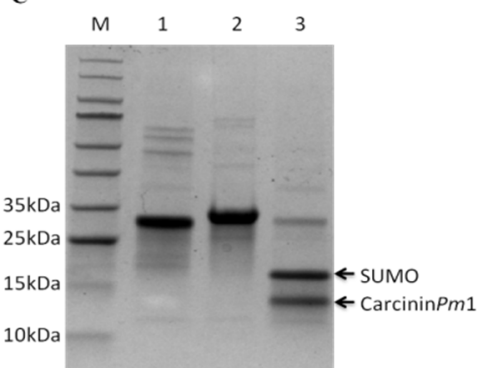

Fig. 6. Heterologous expression and purification of Carcinin $P m 1$ analyzed by SDS-PAGE. M, Protein marker. A, Over-expression of Carcinin Pm 1 in E. coli (BL21). 1, total protein of E. coli without induction; 2, total protein of E. coli induced with $1 \mathrm{mM}$ IPTG at $16^{\circ} \mathrm{C}$ for 12 hours, the fusion protein is indicated by an arrow; 3, supernatant after cell disruption; 4, sediment after cell disruption. B, Purification of CarcininPm 1 by Ni-NTA column. 1, sample, which is the supernatant after cell disruption; 2, flowthrough; 3 and 5, wash off protein with $60 \mathrm{mM}$ imidazole; 4 and 7 , eluted proteins with $200 \mathrm{mM}$ and 500mM imidazole. C, SUMO tag cleavage. 1 , purified protein before cleavage; 2 , SUMO protease; 3, protein after cleavage, with SUMO and Carcinin $P m 1$ indicated.

\section{Discussion}

Type I crustins normally contain a cysteine-rich domain and a WAP domain. The cysteine-rich domain forms two disulfide bridges and the WAP domain contains four disulfide bridges[20]. However, the WAP domain of CarcininPmlwas not intact, as it lacked two cysteins, the second and seventh cysteines in the WAP domain. And these two cysteines normally form a disulfide bridge. This indicates that there were in total three disulfide bridges in the WAP domain of CarcininPm1. The MjCru I-4 and 5 are also ten-cysteine crustins [24]. And there are some Type Icrustins contain sevencysteines in the WAP domain [21]. However, most of Type I crustins have 12 cysteines with an intact WAP domain [23].

Although there are many types of crustins discovered in $P$. monodon, the trancriptome sequencing data showed that most of them were not up-regulated during Vibrio challenge, but the expression level of CarcininPm 1 increased about 15 times post infection, which means that it might play an important role in the innate immunity of $P$. monodon. The most significant upregulation was in hepatopancreas, heart, stomach and gills. As the normal expression level in gills was high, Carcinin $P m 1$ was abundantly transcribed in gills post challenge. The up-regulationcould be observed at $2 \mathrm{~h}$ post challenge, which means that Carcinin $P m 1$ responded to Vibrio challenge in a very short time. And the upregulation lasted at least 12 hours in hepatopancreas. Besides Vibrio, Type I crustinscould also be upregulated by other pathogens. A type-I crustin from red swamp crayfish Procambarus clarkii was significantly induced by Staphylococcusaureus, Vibrio anguillarum and Aeromonas hydrophila stimulations, with the relative expression level only increased about 5 times. It could also be induced by WSSV in hemocyte from $48 \mathrm{~h}$ post-infection[20]. MjCru I-1 was also observed to upregulate about 15 and 10 times at $12 \mathrm{~h}$ post challenged by $S$. aureusand $V$. anguillarum, respectively [25].

In this research, we used a novel method to express Carcinin $P m 1$, and the expression and purification were successful, which indicates that this method could be applied for overexpression of other crustins.
In summary, Carcinin $P m 1$ is a very important molecule in $P$. monodon during fighting against Vibrios. However, it is still unknown about how it functionedin vivo and the in vitro activities need to be further clarified.

\section{Acknowledgements}

This research was supported by the National Natural Science Foundation ofChina [31470389], the ShenzhenGrant Plan for Science \& Technology [JCYJ20160422171614147, JCYJ20170818101523761].

\section{References}

1. Y. Li, Q. Xiang, Q. Zhang, Y. Huang, and Z. Su, Peptides 37, 207 (2012).

2. P. De Schryver, T. Defoirdt, and P. Sorgeloos, PLoS Pathog. 10, e1003919 (2014).

3. T. W. Flegel, J. Invertebr. Pathol. 110, 166 (2012).

4. F. Li and J. Xiang, Dev. Comp. Immunol. 39, 11 (2013).

5. P. Supungul, P. Jaree, K. Somboonwiwat, W. Junprung, P. Proespraiwong, R. Mavichak, and A. Tassanakajon, Aquaculture Research 48, 809 (2017).

6. A. Tassanakajon, V. Rimphanitchayakit, S. Visetnan, P. Amparyup, K. Somboonwiwat, W. Charoensapsri, and S. Tang, Dev. Comp. Immunol. 80, 81 (2018).

7. A. Tassanakajon, K. Somboonwiwat, P. Supungul, and S. Tang, Fish Shellfish Immunol. 34, 954 (2013).

8. D. Destoumieux-Garzón, R. D. Rosa, P. Schmitt, C. Barreto, J. Vidal-Dupiol, G. Mitta, Y. Gueguen, and E. Bachère, Philos. Trans. R. Soc. Lond., B, Biol. Sci. 371, (2016).

9. A. Tassanakajon, K. Somboonwiwat, and P. Amparyup, Dev. Comp. Immunol. 48, 324 (2015).

10. V. J. Smith, J. M. O. Fernandes, G. D. Kemp, and C. Hauton, Developmental \& Comparative Immunology 32, 758 (2008).

11. V. J. Smith, Biochemical Society Transactions 39, 
1403 (2011).

12. S. Donpudsa, S. Visetnan, P. Supungul, S. Tang, A. Tassanakajon, and V. Rimphanitchayakit, Dev. Comp. Immunol. 47, 95 (2014).

13. K. Krusong, P. Poolpipat, P. Supungul, and A. Tassanakajon, Dev. Comp. Immunol. 36, 208 (2012).

14. S. Arayamethakorn, P. Supungul, A. Tassanakajon, and K. Krusong, Dev. Comp. Immunol. 67, 18 (2017).

15. T. Vatanavicharn, P. Supungul, N. Puanglarp, W. Yingvilasprasert, and A. Tassanakajon, Comp. Biochem. Physiol. B, Biochem. Mol. Biol. 153, 244 (2009).

16. P. Amparyup, S. Donpudsa, and A. Tassanakajon, Dev. Comp. Immunol. 32, 1497 (2008).

17. P. Suthianthong, N. Pulsook, P. Supungul, A. Tassanakajon, and V. Rimphanitchayakit, Fish \& Shellfish Immunology 30, 783 (2011).

18. V. V. Afsal, S. P. Antony, A. R. Bright, and R. Philip, Cell. Immunol. 284, 45 (2013).

19. C. Mu, P. Zheng, J. Zhao, L. Wang, H. Zhang, L. Qiu, Y. Gai, and L. Song, Dev. Comp. Immunol. 34, 734 (2010).

20. N. Liu, R.-R. Zhang, Z.-X. Fan, X.-F. Zhao, X.-W. Wang, and J.-X. Wang, Dev. Comp. Immunol. 61, 145 (2016).

21. S. Donpudsa, V. Rimphanitchayakit, A. Tassanakajon, I. Söderhäll, and K. Söderhäll, J. Invertebr. Pathol. 104, 234 (2010).

22. A.-Q. Yu, Y.-H. Shi, and Q. Wang, Fish Shellfish Immunol. 48, 30 (2016).

23. M. Kim, J.-M. Jeon, C.-W. Oh, Y. M. Kim, D. S. Lee, C.-K. Kang, and H.-W. Kim, Comp. Biochem. Physiol. B, Biochem. Mol. Biol. 163, 161 (2012).

24. H.-S. Jiang, W.-M. Jia, X.-F. Zhao, and J.-X. Wang, Fish Shellfish Immunol. 43, 387 (2015).

25. N. Liu, J.-F. Lan, J.-J. Sun, W.-M. Jia, X.-F. Zhao, and J.-X. Wang, Dev. Comp. Immunol. 49, 313 (2015).

26. J. M. Relf, J. R. Chisholm, G. D. Kemp, and V. J. Smith, Eur. J. Biochem. 264, 350 (1999).

27. X. Robert and P. Gouet, Nucleic Acids Res 42, W320 (2014). 